\title{
Factors that influence the perceived advantages and relevance of Facebook as a learning tool: An extension of the UTAUT
}

\author{
Tomás Escobar-Rodríguez, Elena Carvajal-Trujillo and Pedro Monge-Lozano \\ University of Huelva. Spain
}

\begin{abstract}
Social media technologies are becoming a fundamental component of education. This study extends the Unified Theory of Acceptance and Use of Technology (UTAUT) to identify factors that influence the perceived advantages and relevance of Facebook as a learning tool. The proposed model is based on previous models of UTAUT. Constructs from previous models were used such as performance expectancy, effort expectancy, social influence, facilitating conditions, hedonic motivation and habit. Additionally, two new perspectives were added: perceived advantages and perceived relevance of Facebook as a social media platform. It provides some insights into students' behavioural intentions, and such an understanding can help faculty to examine their assumptions about the role of social media technologies in the teaching and learning process. The study participants were students enrolled in a Spanish public university. Data from 956 usable questionnaires were tested against the research model. Our results provide support to the model and reveal a good model fit. In light of these findings, implications for theory and practice are discussed.
\end{abstract}

\section{Introduction}

Social media technologies are progressively incorporated into the learning and teaching process (Jimoyiannis \& Angelaina, 2012; Martin, Diaz, Sancristobal, Gil, Castro \& Peire, 2011; Sadaf, Newby, \& Ertmer , 2012; Veletsianos, 2012). These new technologies allow users to connect, communicate and interact with each other (Correa, Hinsley \& Gil de Zúñiga, 2010), often by posting, sharing, or coproducing information (Kushin \& Yamamoto, 2010). One of the most commonly cited benefits of social media use by students is their ability to facilitate collaboration and communication among them (Rowlands, Nicholas, Russell, Canty \& Watkinson, 2011), as well as information dissemination (Luzon, 2009). Moreover, unlike other technologies, there are aspects that facilitate the use of social media technologies during the learning/teaching process such as students voluntarily using different social media technologies and already having the necessary technical skills (Dohn, 2009).

Facebook is the most popular social media technology among university students (Christy, Cheung, Chiu \& Lee, 2011). It allows users to broadcast messages to large audiences using status updates and wall posts, while also providing features such as chat, for messages the user wishes to keep private (Smock, Ellison, Lampe \& Wohn, 2011). Moreover, Facebook creates an online social space where university students can build and maintain social capital with others (Ellison, Steinfield \& Lampe, 2007), as well as to build social capital with the industry (Chakrabarti \& Santoro, 2004).

The number of Facebook users has continued to increase. By the end 2012, there were approximately one billion monthly active users and 584 million daily active users on average (http://newsroom.fb.com/KeyFacts). Significant progress has been made over the last years in explaining the role that Facebook has during the learning/teaching process and a number of studies have been carried out in the context of education.

Davies (2012) explored whether Facebook provides opportunities for new literacy practices through textmaking; the research considered how teenagers use the site to present themselves and "do friendship". She has shown how young people are managing social relationships in new ways via Facebook. Junco (2012), furthermore, examined the relationship between frequency of Facebook use, participation in Facebook activities and student engagement. The study findings indicated that Facebook use was significantly predictive of engagement scale score and of time spent in co-curricular activities.

Gruzd, Staves \& Wilk (2012) investigated why and how scholars are using social media. Results indicate that because non-academic social networking tools, such as Facebook, are popular among the general 
public, they have been adopted by scholars and eventually used in their professional lives. Scholars are turning to Facebook because it is more convenient for making new connections with peers and collaboration. It could be an opportunity to use Facebook as an effective teaching tool. Additionally, the scholars who are now in university belong to the generation named Millennials, Net Generation, or Generation Y, were born in the 1980s or early 1990s (Baird \& Fisher, 2005-2006; Barnes et al., 2007; Everson, Gundlach \& Miller, in press). These scholars multitask, like to work in a flexible classroom where their privacy is respected and they receive feedback and want knowledge to be applied to the "real world" (Westerman, 2006-2007). As the scholars are using Facebook in their everyday lives, they can be very motivated when the faculty uses Facebook to meet them where they are (Everson et al., in press). Furthermore, for some previously disadvantaged students with limited self-esteem and communicative competence, Facebook embodies a prospective 'mouth piece' for their democratic self-expression (Rambe, 2012).

Students appear to be open-minded about the prospect of using Facebook for educational purposes (McCarthy, 2013; Roblyer, McDaniel, Webb, Herman \& Witty, 2010). However, despite the potential and general enthusiasm for Facebook, it has not been taken up extensively in education yet. This might be the result of a sentiment among students that Facebook is a place to socialise and thus should be kept separate from academic work (Hew, 2011). One of the barriers to the adoption of Facebook as a learning tool could be students' perceptions regarding technology use in personal space versus learning spaces. Most students rarely use social media for educational purposes because they tend to separate their social life (pleasure) from their learning (pain) (Jones, Blackey, Fitzgibbon \& Chew, 2010). Although students seem positive about their experiences with Facebook as a learning tool, they appear to consider Facebook to be more of a "social study space" that is off limits to university staff, and this led to questions about whether faculty would do more harm than good by trying to formalize the use of Facebook in the classroom (Gray, Annabell \& Kennedy, 2010). Because of the terminology used to define Facebook members, students could have difficulty understanding why some people may want to connect with them through it. So, if Facebook defines connections as "friends", students could have a hard time understanding why university staff want to connect with them as "friends" (Rambe, 2013).

Facebook combines a confusing array of tools, sometimes making navigation around these sites difficult, resulting in a lack of clarity for non-experts users as to where to post information or which channel to use for communication. Furthermore, Facebook is equipped with tools like bulletin boards, instant messaging, and e-mail, and these tools allow for multitasking (Judd, 2013). In social media technologies, multitasking is the norm; but is more prominent among students (Carrier, Cheever, Rosen, Benitez \& Chang, 2009). Because the increased availability of new portable digital technologies has made it possible to use these technologies anywhere and anytime, many individuals regularly access and interact with technologies in every context in their lives including the classroom (Wood et al., 2012). Although these technologies can be harnessed for positive educational outcomes, recent research suggests that these same digital technologies can impair performance and distract students if used inappropriately (Fried, 2008).

Multitasking is the execution of two or more cognitive or information processing activities simultaneously (Karpinski, Kirschner, Ozer, Mellott \& Ochwo, 2013; Pashler, 1994). Research has shown that multitasking leads to poorer learning results and performance on tasks when compared to serially carrying out those same tasks (Fox, Rosen \& Crawford, 2009). Furthermore, several studies show that when students have access to laptops in the classroom, they often engage in distractive multitasking behaviors, which is associated with a decrement in academic performance (Junco \& Cotton, 2012). Moreover, Rubinstein, Meyer \& Evans (2001) found that people who were required to multitask took longer to finish their tasks than it would take them to finish them if they concentrated on one task at a time. The increase in task duration when multitasking was attributed to lost time from switching back and forth between the tasks, especially when the tasks became more complex (Rosen, Carrier \& Cheever, 2013).

On the other hand, Facebook offers a variety of intrinsically interesting activities to perform (viewing pictures, chatting with friends, playing games, posting status updates etc.) that can all be performed within a single site and it provides users with a multitude of stimuli to explore and act on (Junco \& Cotton, 2011). These interesting features also may make Facebook particularly distracting (Wood et al., 2012). Therefore, the use of Facebook during the teaching-learning process is likely to sometimes be detrimental to learning. 
Recently, Hew (2011) reviewed current published research studies focusing on the use of Facebook by students and teachers. Three major topics of current research were identified: (1) students' Facebook usage profile or extent of Facebook use, (2) the effects of Facebook use and (3) students' attitudes towards Facebook.

Despite the increased importance of Facebook as a social media technology, few studies have been conducted in the academic area regarding students' intention to use Facebook during the learning/teaching process. The acceptance and/or use by students of some information technologies (such as e-learning platforms, flexible online learning technologies, web-based learning environment and so on) have been traditionally analysed employing different theoretical models, for example, the Technology Acceptance Model (Davis, 1989), the Theory of Planned Behavior (Schifter \& Azjen, 1985) and the Unified Theory of Acceptance and Use of Technology (UTAUT) (Venkatesh, Morris, Davis \& Davis, 2003).

This study proposes a model to explain students' intention to use Facebook during the learning/teaching process, which incorporates UTAUT basic explanatory variables (i.e., performance expectancy, effort expectancy, social influence, facilitating conditions) as well as the adaptation of other explanatory variables such as hedonic motivation and habit. In addition to these six main factors, the model includes two perspectives - perceived advantages and perceived relevance of Facebook as a social media platform - that may help to explain the influence of the six main constructs on the dependent variables, students' behavioural intention of using Facebook as a learning tool. The remainder of the paper proceeds as follows. In the next section, we provide the literature review. We then propose our working hypotheses and describe the research methodology. Finally, we present the data analysis, results and discussion sections.

\section{Theory and Hypotheses}

The acceptance and use of Facebook during the learning/teaching process is a behaviour which can be explained by extending UTAUT (Venkatesh et al., 2003). UTAUT was originally created in order to understand the factors that influence employee information technology acceptance and use. Nevertheless, several studies have applied it to an educational context. In this latter regard, UTAUT has been applied in technologies such as mobile learning (Wang, Wu \& Wang, 2009), computer based assessment (Terzis \& Economides, 2011), e-learning systems (Chen, 2011) and web 2.0 (Huang, Hood \& Yoo, 2013).

UTAUT explains intention to use a technology and synthesises eight theoretical models from psychological and sociological theories used in the literature to explain this behaviour (Venkatesh et al., 2003). UTAUT considers four main constructs: performance expectancy, effort expectancy, social influence and facilitating conditions. Performance expectancy is "the degree to which an individual believes that using the system will help him or her to attain gains in job performance" (Venkatesh et al., 2003:447). Effort expectancy is defined as "the degree of ease associated with the use of the system". Social Influence is "the degree to which an individual perceives that important others believe he or she should use the new system" (Venkatesh et al., 2003:450). Lastly, facilitating conditions is considered as "the degree to which an individual believes that an organizational and technical infrastructure exists to support use of the system" (Venkatesh et al., 2003:453).

To understand better students' behaviour regarding Facebook during the teaching and learning process, we will extend UTAUT by incorporating in our model two additional constructs: hedonic motivation and habit. Hedonic motivation can be defined as "the fun or pleasure derived from using a technology" (Brown \& Venkatesh 2005), and habit is "the extent to which people tend to perform behaviours automatically because of learning” (Limayem, Hirt \& Cheung, 2007:705).

The incorporation of the hedonic motivation construct extends UTAUT, which only considers extrinsic motivation or utilitarian value through the performance expectancy construct (Venkatesh, Thong \& Xu, 2012). The performance expectancy construct has proved to be the strongest predictor of use intention (Venkatesh et al., 2003). Hedonic motivation has been described as perceived enjoyment in numerous papers on information technology, which have demonstrated their influence on intention to use technology and technology use (van der Heijden 2004; Thong, Hong \& Tam, 2006). 
The habit construct has been used in several papers as a predictor of technology use (Kim \& Malhotra, 2005; Kim, Malhotra \& Narasimhan, 2005; Limayem et al., 2007). Kim, Malhotra \& Narasimhan (2005) associate habit with automaticity. However, operationalisation has been realised in different ways; while for Kim and Malhotra (2005) habit is comparable to prior behaviour, for Limayem et al. (2007) it is the extent to which an individual believes his behaviour is automatic. We follow Limayem et al. (2007) in operationalising habit, that is to say, as a self-reported perception. According to the approximation of Limayem et al. (2007), who operationalise habit following a perception-based approach, habit has a direct effect on technology use and, furthermore, a more moderate effect on intention, since intention to use technology is of less importance as habit increases (Limayem et al., 2007). Kim and Malhotra (2005) showed that prior use (operationalisation of habit) is a very relevant factor in technology use.

To sum up, we establish that students' intention to use Facebook during the teaching/learning process is influenced by six constructs: (i) performance expectancy; (ii) effort expectancy; (iii) social influence; (iv) facilitating conditions; (v) hedonic motivation; and (vi) habit. Additionally, to analyse these relationships more effectively, we have included in the study two perspectives that summarise the two major reasons why students could show a positive attitude towards using Facebook during the learning/teaching process: perceived advantages and perceived relevance of Facebook as a social media platform.

By using these two perspectives we try to have a better knowledge about factors influencing the students' intention to use Facebook as a learning tool as well as to get a model that allows us to have a simpler point of view about these relationships. Traditionally, the UTAUT model and its application assumes that all factors directly affect the intention to use an information technology. The proposed model uses two perspectives to group the six constructs according to why the student would use Facebook as a learning tool.

On the one hand, students could be interested in using Facebook because they assume that it can offer some advantages as a social media technology that could really be a powerful learning tool. Facebook can positively impact a college student's life. For example, students can use Facebook to contact other students concerning course assignments or group projects, and teachers can contact their students regarding useful course links (Muñoz \& Towner, 2009). This perspective would be connected to performance expectancy, effort expectancy and hedonic motivation. We have considered these three constructs in this perspective because all of them seem to be related to individual perceptions about the use of Facebook and they do not take into account social influences to explain user intentions.

On the other hand, students' behaviour could be related to the perceived relevance of Facebook as a social media platform. Facebook is one of the leading social media platforms and students may show a more positive attitude towards using it in their studies for this reason, regardless of their relative advantages. This perspective would be related to the social influence, facilitating conditions and habit. These three constructs deal with other issues that could influence the behavioral intentions regarding other aspects that are not directly related to Facebook itself as a technology. 


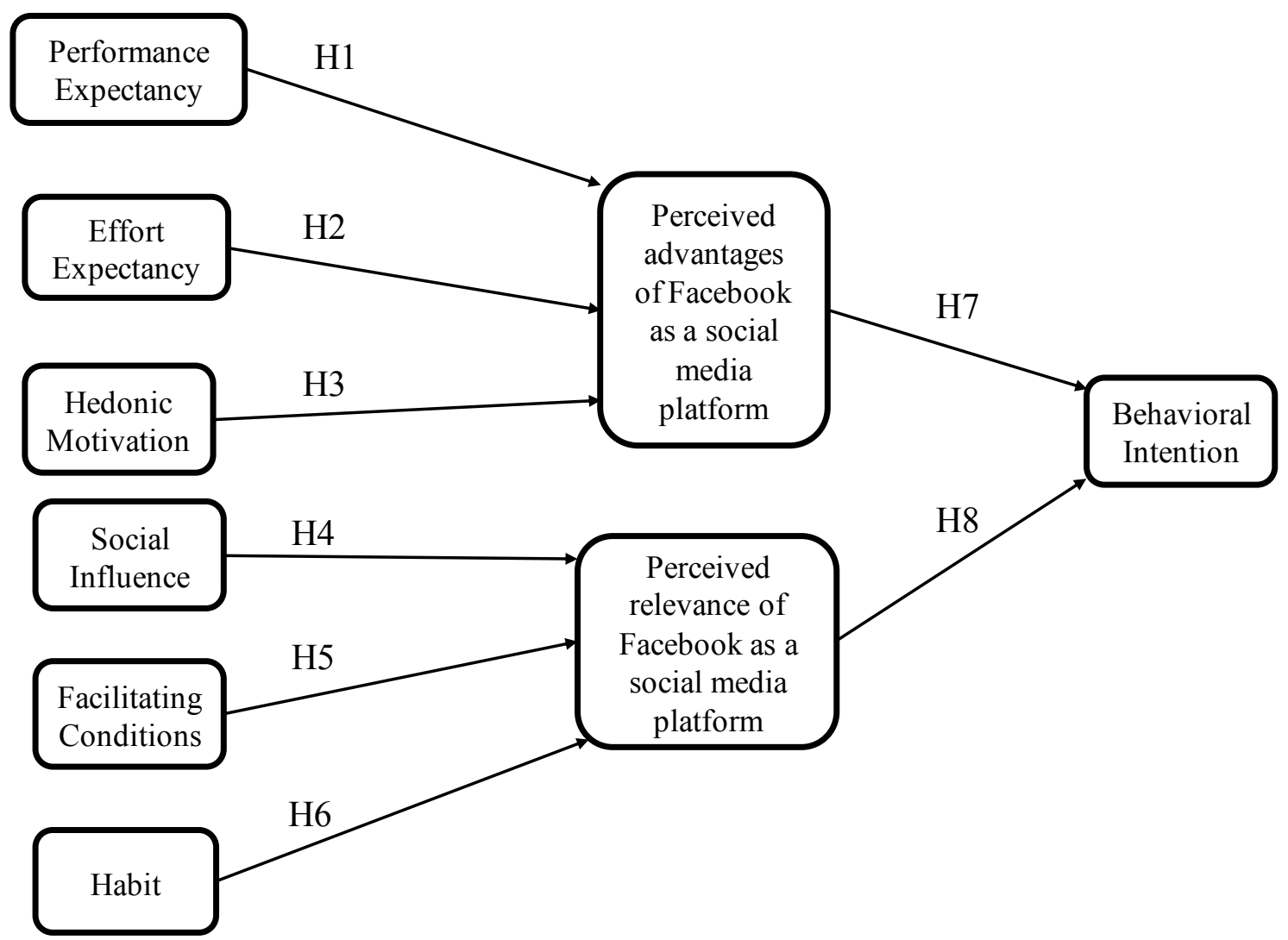

Figure 1. Research model and hypotheses.

The proposed model (Figure 1) has nine constructs and eight hypotheses have been generated from the relations among them:

H1. The performance expectancy in the use of Facebook during the teaching/learning process positively affects perceived advantages of Facebook as a social media platform.

H2. The effort expectancy in the use of Facebook positively affects perceived advantages of Facebook as a social media platform.

H3. The hedonic motivation in the use of Facebook positively affects perceived advantages of Facebook as a social media platform.

H4. The social influence in the use of Facebook positively affects perceived relevance of Facebook as a social media platform.

H5. The facilitating conditions in the use of Facebook positively affect perceived relevance of Facebook as a social media platform.

H6. The habit in the use of Facebook positively affects perceived relevance of Facebook as a social media platform.

H7. The perceived advantages of Facebook as a social media platform positively affect behavioural intention of using during the teaching/learning process.

H8. The perceived relevance of Facebook as a social media platform positively affects behavioural intention of using during the teaching/learning process. 


\section{Methodology}

Theoretical constructs were measured using validated items from prior research. Performance expectancy, Effort expectancy, Hedonic motivation, Social Influence, Facilitating conditions and Habit were measured using items adapted from Venkatesh et al. (2012). Measurements for Perceived relevance of Facebook as a social media platform were developed from the study of Lopez-Nicolas, Molina-Castillo \& Bouwman (2008), with modifications to fit the specific context of Facebook as a learning tool. Items for Behavioural Intention were adapted from Terzis, Moridis \& Economides (2012) and Venkatesh et al. (2012). Items for Perceived advantages of Facebook as a social media platform were developed for this research. Table 2 provides a detailed summary of the twenty-seven items measured through a seven-point Likert scale. This seven-point scale anchored from 1 (strongly disagree) to 7 (strongly agree). With this scale variables can be measured that are not directly observed or quantifiable (Churchill \& Iacobucci, 2002).

In order to validate the questionnaire, students and academics assessed whether these items were likely to be appropriate for the aim of studying the acceptance of Facebook during the teaching/learning process. On the basis of the comments realised, modifications were made to this instrument such as the rewording of some items for reason of clarity. Following this, a pre-test was conducted on 100 randomly selected students of different genders and courses. During the pretest, subjects who had not previously used Facebook were eliminated. Based on the results of this pre-test, only minor modifications were made to the wording of some items to further increase their clarity. Minor modifications were made in few words highlighted as unclear when the questionnaire was administered to these 100 students.

A questionnaire was created in English and this was administered in Spanish for students who have used Facebook. The English questionnaire was translated into Spanish by a professional native English translator and researchers independently translated the English questionnaire into Spanish. After analysing the different independently translated Spanish questionnaires, the final version of the questionnaire was agreed on. This final Spanish questionnaire was translated back into English by another professional native English translator to ensure the consistency between the Spanish and the English versions of the questionnaire (Brislin, 1970).

The study took place among students of Business Administration in a Spanish public university. The interviewers were trained in different sessions in the technique for administering the questionnaire to students who were Facebook users. In this way, participants had to satisfy certain criteria. Students were all asked to meet the following criteria: they had an active Facebook profile and used Facebook regularly to meet peers, share ideas, and collaborate. We have allowed those who had not used Facebook during the teaching/learning process to participate in the study because we are investigating intentions to use Facebook as a learning tool and not for actual use. However, we have not included in the study those students who are not Facebook users because we argue that they do not really know what Facebook is and how it works.

From 15 October to 14 December, 2012 the main survey was administered to 1,200 students. The subjects completed 1,034 (86.17\%) questionnaires, 956 (79.67\%) of which were collected for data analysis, after eliminating some questionnaires that had been deemed unusable. Table 1 shows the gender and age of the respondent subjects. There were more males $(52.72 \%)$ than females $(47.28 \%)$. The largest group of respondents $(49.06 \%)$ was the 20 to 21 age group, followed by ages below $20(26.05 \%)$, and ages 22 to $23(17.99 \%)$. 
Table 1

Gender and age characteristics of respondents

\begin{tabular}{lccc}
\hline & Characteristics & Frequency & $\%$ \\
\hline Gender & Male & 504 & 52.72 \\
& Female & 452 & 47.28 \\
& Total & 956 & 100.00 \\
Age & & & \\
& $<20$ & 249 & 26.05 \\
& $20-21$ & 469 & 49.06 \\
& $22-23$ & 172 & 17.99 \\
& $>23$ & 66 & 6.90 \\
& Total & 956 & 100.00 \\
\hline
\end{tabular}

\section{Data analysis and results}

This research is based on a regression analysis of latent variables using the optimisation technique of the Partial Least Squares (PLS) to develop a model that represents the relationships between the nine proposed constructs measured by many items. The PLS is a multivariate technique to test structural models (Wold, 1985). The PLS method estimates the model parameters which minimise the residual variance of the whole model dependent variables (Hsu, Chen \& Hsieh, 2006), does not require any parametric conditions (Chin, 1998) and is recommended for small samples (Hulland, 1999).

The analysis of data took place through a two-stage methodology, in which the measurement model is developed first and evaluated separately from the full structural equation model (Gerbing \& Anderson, 1988). Therefore, the first step involves establishing individual reliability for each item and the convergent and discriminate validity of the constructs.

The individual reliability for each item is given by loadings or correlations between the item and the construct. The convergent validity of each item is acceptable for a loading higher than 0.505 (Falk \& Miller, 1992). Table 2 indicates the loadings and descriptive statistics for each item. They all comply with established conditions.

Reliability makes it possible to measure internal coherence of all the indicators in relation to constructs. In order to verify the reliability of indicators, the Cronbach coefficient alpha (Cronbach, 1970) and the composite reliabilities coefficient (Werts, Linn \& Jöreskog, 1974) were utilised, which range from 0 (no similarities) and 1 (maximum similarities). Both parameters are considered, as the first shows that the contribution made by each indicator is similar, while the second takes the respective indicators into account. Table 3 indicates the values of each coefficient. Composite reliabilities are over the minimum acceptable limit of 0.70 (Gefen, Straub \& Boudreau, 2000; Nunnally, 1978). The Cronbach coefficient alpha levels are also shown in Table 3 . They are all above 0.70 , which is recommended for confirmatory research (Churchill, 1979).

Convergent validity represents the common variance between the indicators and their construct. It is measured by the Average Variance Extracted (AVE), and the acceptable threshold should be higher than 0.50 (Fornell \& Larcker, 1981). Table 3 presents the AVE scores achieved for each of the nine constructs employed, which in all cases surpasses the minimum desirable value.

In order to confirm the discriminant validity among constructs, the AVE square root must be superior to the correlation between constructs (Fornell \& Larcker, 1981). Table 4 indicates the square roots of the AVE (in the diagonal) and the correlation among constructs. It suggests adequate discriminant validity of the measurements. 
Table 2

Items loading and descriptive statistics (*) Reversed scaled construct

\begin{tabular}{|c|c|c|c|c|}
\hline Construct & Item & Loading & Mean & SD \\
\hline \multirow{3}{*}{$\begin{array}{l}\text { Performance } \\
\text { Expectancy } \\
\text { (PE) }\end{array}$} & PE1. I would find Facebook useful in my studies. & 0.88 & 5.16 & 1.40 \\
\hline & $\begin{array}{l}\text { PE2. Using Facebook in my studies would allow } \\
\text { me to accomplish more work than would } \\
\text { otherwise be possible. }\end{array}$ & 0.93 & 5.33 & 1.48 \\
\hline & $\begin{array}{l}\text { PE3. Using Facebook in my studies would reduce } \\
\text { the time I spend on unproductive activities. }\end{array}$ & 0.90 & 5.44 & 1.46 \\
\hline \multirow{3}{*}{$\begin{array}{l}\text { Effort } \\
\text { Expectancy }\left(^{*}\right) \\
\text { (EE) }\end{array}$} & $\begin{array}{l}\text { EE1. Learning how to use Facebook is easy for } \\
\text { me. }\end{array}$ & 0.73 & 5.04 & 2.74 \\
\hline & $\begin{array}{l}\text { EE2. My interaction with Facebook is clear and } \\
\text { understandable. }\end{array}$ & 0.91 & 4.83 & 1.50 \\
\hline & EE3. I find Facebook easy to use. & 0.90 & 4.89 & 1.52 \\
\hline \multirow{3}{*}{$\begin{array}{l}\text { Hedonic } \\
\text { Motivation } \\
\text { (HM) }\end{array}$} & HM1. Using Facebook is fun. & 0.92 & 4.36 & 1.61 \\
\hline & HM2. Using Facebook is enjoyable. & 0.92 & 4.53 & 1.50 \\
\hline & HM3. Using Facebook is very entertaining. & 0.91 & 4.47 & 1.64 \\
\hline \multirow{3}{*}{$\begin{array}{l}\text { Social } \\
\text { Influence } \\
\text { (SI) }\end{array}$} & $\begin{array}{l}\text { SI1. People who are important to me think that I } \\
\text { should use Facebook. }\end{array}$ & 0.91 & 4.38 & 1.57 \\
\hline & $\begin{array}{l}\text { SI2. People who influence my behaviour think } \\
\text { that I should use Facebook. }\end{array}$ & 0.93 & 4.24 & 1.61 \\
\hline & $\begin{array}{l}\text { SI3. People whose opinions I value prefer that I } \\
\text { use Facebook. }\end{array}$ & 0.91 & 4.40 & 1.59 \\
\hline \multirow{3}{*}{$\begin{array}{l}\text { Facilitating } \\
\text { Conditions (FC) }\end{array}$} & $\begin{array}{l}\text { FC1. I have the resources necessary to use } \\
\text { Facebook. }\end{array}$ & 0.80 & 5.68 & 1.45 \\
\hline & $\begin{array}{l}\text { FC2. I have the knowledge necessary to use } \\
\text { Facebook. }\end{array}$ & 0.90 & 5.22 & 1.57 \\
\hline & FC3. I feel comfortable using Facebook. & 0.87 & 4.93 & 1.63 \\
\hline \multirow{3}{*}{ Habit (HT) } & $\begin{array}{l}\text { HT1. The use of Facebook has become a habit for } \\
\text { me. }\end{array}$ & 0.89 & 3.97 & 1.76 \\
\hline & HT2. I am addicted to using Facebook. & 0.87 & 2.90 & 1.84 \\
\hline & HT3. I must use Facebook. & 0.90 & 3.86 & 1.78 \\
\hline \multirow{3}{*}{$\begin{array}{l}\text { Perceived } \\
\text { advantages of } \\
\text { Facebook as a } \\
\text { social media } \\
\text { platform (PA) }\end{array}$} & $\begin{array}{l}\text { PA1. Using Facebook would lead to my } \\
\text { exploration of new perspectives during the } \\
\text { learning process. }\end{array}$ & 0.93 & 4.95 & 1.66 \\
\hline & $\begin{array}{l}\text { PA2. Using Facebook would give me more } \\
\text { possibilities to pass my subjects. }\end{array}$ & 0.94 & 4.78 & 1.65 \\
\hline & $\begin{array}{l}\text { PA3. Facebook would be a powerful learning tool } \\
\text { in my studies. }\end{array}$ & 0.95 & 4.86 & 1.66 \\
\hline \multirow{3}{*}{$\begin{array}{l}\text { Perceived } \\
\text { relevance of } \\
\text { Facebook as a } \\
\text { social media } \\
\text { platform (PR) }\end{array}$} & $\begin{array}{l}\text { PR1. People who do not use Facebook are not in } \\
\text { touch with today's reality. }\end{array}$ & 0.87 & 3.61 & 1.80 \\
\hline & PR2. Not using Facebook is simply not an option. & 0.83 & 3.61 & 1.93 \\
\hline & $\begin{array}{l}\text { PR3. People who do not use Facebook are not in } \\
\text { tune with today's reality. }\end{array}$ & 0.77 & 4.08 & 1.96 \\
\hline \multirow{3}{*}{$\begin{array}{l}\text { Behavioural } \\
\text { Intention (BI) }\end{array}$} & $\begin{array}{l}\text { BI1. I intend to use Facebook in my studies when } \\
\text { it becomes available. }\end{array}$ & 0.93 & 4.26 & 1.65 \\
\hline & $\begin{array}{l}\text { BI2. I intend to use Facebook in my studies as } \\
\text { often as needed. }\end{array}$ & 0.90 & 4.15 & 1.76 \\
\hline & $\begin{array}{l}\text { BI3. I predict I would use Facebook in my studies } \\
\text { in the future. }\end{array}$ & 0.84 & 4.08 & 1.97 \\
\hline
\end{tabular}


Table 3

Composite reliability, AVE and Cronbach coefficient alpha

\begin{tabular}{lccc}
\hline Construct & Composite Reliability & AVE & Cronbach Alpha \\
\hline Performance Expectancy (PE) & 0.93 & 0.82 & 0.89 \\
Effort Expectancy (EE) & 0.89 & 0.72 & 0.80 \\
Hedonic Motivation (HM) & 0.95 & 0.84 & 0.91 \\
Social Influence (SI) & 0.94 & 0.84 & 0.91 \\
Facilitating Conditions (FC) & 0.89 & 0.74 & 0.82 \\
Habit (HT) & 0.92 & 0.79 & 0.86 \\
Perceived advantages of & 0.96 & 0.88 & 0.93 \\
Facebook as a social media & & & \\
platform (PA) & 0.86 & 0.68 & 0.76 \\
Perceived relevance of Facebook & 0.92 & 0.79 & 0.86 \\
as a social media platform (PR) & &
\end{tabular}

Table 4

Discriminant validity of constructs

\begin{tabular}{cccccccccc}
\hline & PE & EE & HM & SI & FC & HT & PA & PR & BI \\
\hline PE & $\mathbf{0 . 9 0}$ & & & & & & & & \\
EE & 0.67 & $\mathbf{0 . 8 5}$ & & & & & & & \\
HM & 0.52 & 0.55 & $\mathbf{0 . 9 2}$ & & & & & & \\
SI & 0.40 & 0.37 & 0.49 & $\mathbf{0 . 9 2}$ & & & & & \\
FC & 0.66 & 0.75 & 0.56 & 0.39 & $\mathbf{0 . 8 6}$ & & & & \\
HT & 0.40 & 0.47 & 0.52 & 0.43 & 0.43 & $\mathbf{0 . 8 9}$ & & & \\
PA & 0.63 & 0.61 & 0.57 & 0.44 & 0.62 & 0.67 & $\mathbf{0 . 9 4}$ & & \\
PR & 0.40 & 0.43 & 0.44 & 0.35 & 0.42 & 0.60 & 0.59 & $\mathbf{0 . 8 2}$ & \\
BI & 0.48 & 0.52 & 0.47 & 0.36 & 0.54 & 0.63 & 0.69 & 0.80 & $\mathbf{0 . 8 9}$
\end{tabular}

After establishing the individual reliability for each item and the convergent and discriminant validity of the constructs, the structural model is examined. To test $\mathrm{H} 1$ through H8, a PLS analysis is performed. The regression coefficients are based on a bootstrapping of 100 samples and not on a sample estimator. This permits the generalisation of the results and the computation of the t-student statistic for each hypothesis (Lévy, Valenciano \& Michal, 2009). Figure 2 summarises the relationship between the different constructs. The predictive capability of the model is satisfactory because all R-Squares are higher than 0.10 (Falk \& Miller, 1992). 


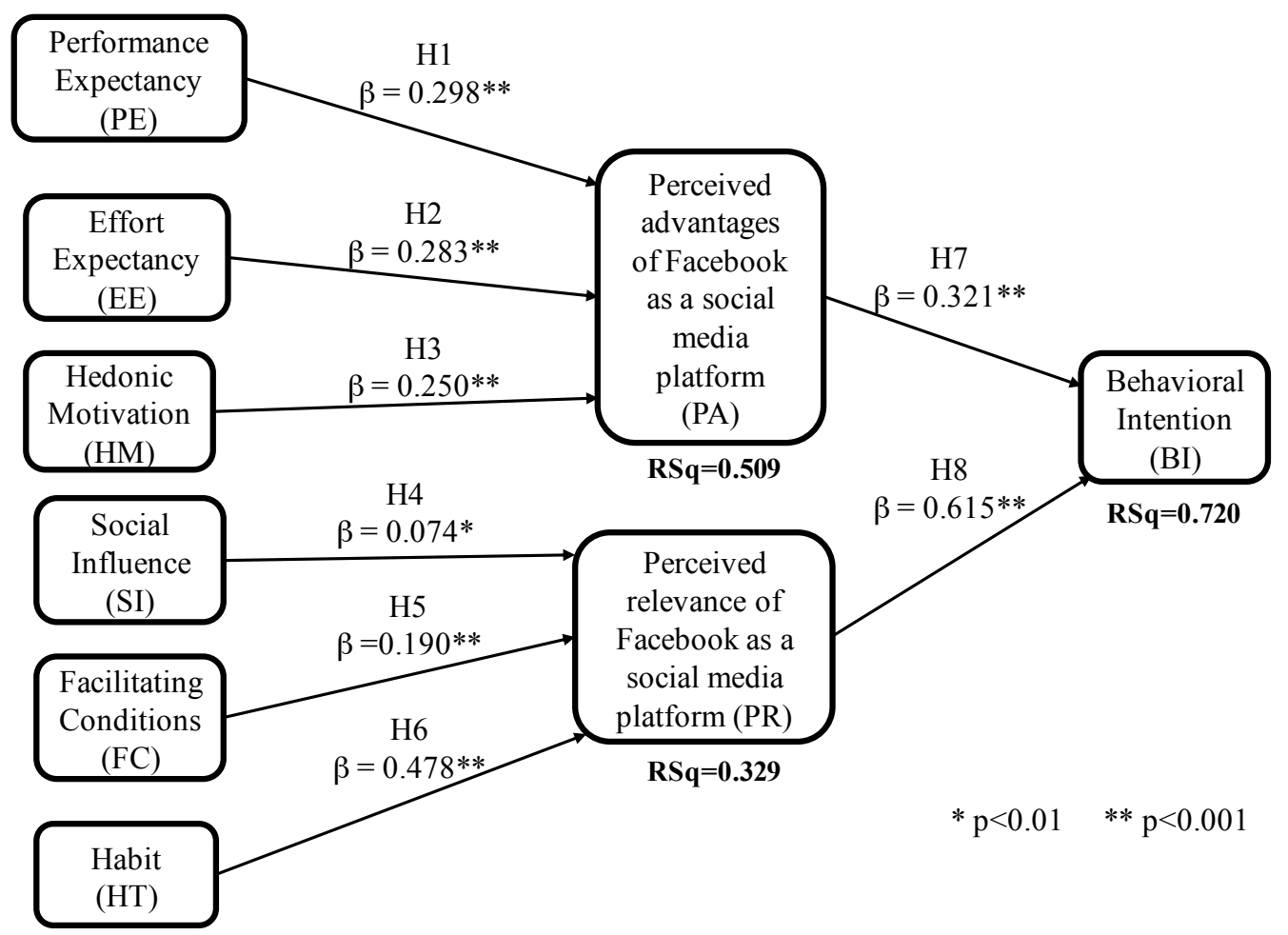

Figure 2. Results of testing model

\section{Discussion and implications}

This study suggests factors that could influence the perceived advantages and relevance of Facebook as a learning tool. These two perspectives have shown significant relationships with students' behavioural intentions to use Facebook in their studies (H7 and H8). The results support the theory that a perception of the advantages and relevance of Facebook has a positive influence on students' intention to use it during the learning/teaching process. The higher each perception, the higher the students' intentions of using Facebook. These two constructs have been found to successfully predict students' behaviour intention $\left(\mathrm{R}^{2}=0.720\right)$. Moreover, the perceived relevance of Facebook $(\mathrm{H} 8, \beta=0.615)$ seems to be more relevant in explaining the attitude towards using it during the learning/teaching process than its perceived advantages $(H 7, \beta=0.321)$. One plausible explanation could be that students are used to thinking of Facebook as a trend rather than a really useful learning platform. Sometimes, students try to enhance their social image by using new technologies (such as Facebook) that have been collectively deemed as modern and rational, instead of improving their performance by taking advantage of their potential capabilities.

In order of importance, perceived relevance of Facebook as a social media platform depends on the individual habit of using Facebook (H6, $\beta=0.478)$, the available facilitating conditions $(\mathrm{H} 5, \beta=0.190)$ and the social influence from referents $(\mathrm{H} 4, \beta=0.074)$. On the other hand, the results highlight that the main predictors of perceived advantages of Facebook as a social media platform are, in order of importance, performance expectancy $(H 1, \beta=0.298)$, effort expectancy $(H 2, \beta=0.283)$, and hedonic motivation $(H 3$, $\beta=0.250)$.

The results indicate that habit is a strong predictor of students' behavioural intention regarding Facebook in their studies, which is consistent with the findings of previous studies (Limayem et al., 2007). It is suggested, therefore, that universities could formulate information technology strategies that include those that are more used by students. This could allow an increase in the students' acceptance of information technology during the learning/teaching process because popular information technologies (such as Facebook) are included. 
Another of the constructs incorporated into our model is hedonic motivation, which has a positive influence on perceived advantages of Facebook as a social media platform $(\mathrm{H} 3, \beta=0.250)$. On the other hand, performance expectancy has also shown a significant relation $(\mathrm{H} 1, \beta=0.298)$ with this construct. This is because Facebook offers many hedonic and utilitarian features to students. Facebook enables hybrid learning spaces that travel across physical and cyber spaces according to principles of collaboration and participation (Greenhow, Robelia, \& Hughes, 2009). Included in utilitarian features we highlight free collaboration, communication and information and the option of using Facebook in personal devices such as smart phones, iPads and so on.

As for hedonic features, Facebook allows users to personalise the information given to each individual and offers a very friendly interface. If learning platforms are easy, fast and user-friendly, it is more likely that students achieve greater hedonic motivation. On the whole, the Facebook page design should be entertaining and fun and include attributes such as photo applications, instant messaging, voice and video calling, events applications and even games to engage students. Moreover, students value the enjoyment obtained from the information technology, which can in turn result in repeat use.

Effort expectancy is the other factor influencing the perceived advantages of Facebook $(\mathrm{H} 2, \beta=0.283)$. The results obtained in this study might be due to the fact that nearly all the individuals included are habituated to using Facebook. The process of adapting to and accepting Facebook during the learning and teaching process may not be the same when technology is totally unfamiliar. This is an important advantage of Facebook because students do not need to learn how to handle the application, just to use a familiar information technology in their studies.

Our findings indicate the effect of social influence $(\mathrm{H} 4, \beta=0.074)$. Students perceive that their referents think they should use Facebook in their studies. As a result, universities should formulate marketing strategies in order to achieve a favorable opinion from referents so they recommend the use of Facebook.

Finally, regarding the influence of facilitating conditions, this variable influences perceived relevance of Facebook as a social media $(\mathrm{H} 5, \beta=0.190)$. This implies that students' perceptions about the resources and support available for Facebook use influence the intention to use it. Nowadays, students can use Facebook anywhere because they can log in using computers, smart phones, iPads and so on. It implies that Facebook is in very good shape for use in universities as a learning platform that complements mainstream e-learning technologies.

\section{Conclusion}

This work contributes to the literature on the factors affecting students' intention to use Facebook during the learning and teaching process. We have considered two perspectives in order to explain why students could use this popular social media platform: perceived advantages and perceived relevance of Facebook as a social media platform. These two constructs have shown positive relations with students' behaviour intention. Additionally, six constructs adapted from the UTAT have been included in the research model: performance expectancy, effort expectancy, social influence, facilitating conditions, hedonic motivation and habit. All of them are relevant to analyse the students' intention to use Facebook in their studies.

Future studies can examine the influence of other constructs on students' behaviour intention. Constructs, such as gender, age, level of education, nationality and students' academic performance can be included. The incorporation of these factors can improve the prediction capacity of the model. Also, future research should analyse this model for other types of social media technologies. This study analysed students' behavioral intention at a single point in time; it is recommended to carry out a similar longitudinal study since individual perceptions change over time. Finally, the identification of those factors that differentially affect information technology acceptance and use according to the online experience of users is recommended. 


\section{References}

Baird, D., \& Fisher, M. (2005-2006). Neomillennial user experience design strategies: Utilizing social networking media to support "always on" learning styles. Journal of Educational Technology Systems, 34, 5-32.

Barnes, K., Marateo, R., \& Ferris, S., (2007). Teaching and learning with the net generation. Innovate, 3.

Brislin, R. W. (1970). Back translation for cross-cultural research. Journal of Cross-Cultural Psychology, l(3), 185-216.

Brown, S.A., \& Venkatesh, V. (2005). Model of Adoption of Technology in the Household: A Baseline Model Test and Extension Incorporating Household Life Cycle. MIS Quarterly, 29(4), 399-426.

Carrier, L. M., Cheever, N. A., Rosen, L. D., Benitez, S., \& Chang, J. (2009). Multitasking across generations: Multitasking choices and difficulty ratings in three generations of Americans. Computers in Human Behavior, 25, 483-489.

Chakrabarti, A. K., \& Santoro, M. D. (2004). Building social capital and learning environment in university-industry relationships. International Journal of Learning and Intellectual Capital, 1(1), 1936.

Chen, J. L. (2011). The effects of education compatibility and technological expectancy on e-learning acceptance.Computers \& Education, 57, 1501-1511.

Chin, W. W. (1998). The partial least squares approach to structural equation modeling. In G. A. Marcoulides (Ed.). Modern methods for business research (pp. 295-336). Mahwah, NJ: Lawrence Erlbaum and Associates.

Christy M. K., Cheung, C. M., Chiu, P. Y., \& Lee, M. K. (2011). Online social networks: Why do students use facebook? Computers in Human Behavior, 27, 1337-1343.

Churchill, G. A. (1979). A paradigm for developing better measures of marketing constructs. Journal of Marketing Research, 16(1), 64-73.

Churchill, G. A., \& Iacobucci, D. (2002). Marketing research methodological foundations (8th ed.). Mason: Thomson.

Correa, T., Hinsley, A. W., \& Gil de Zúñiga, H. (2010). Who interacts on the Web? The intersection of users' personality and social media use. Computers in Human Behavior, 26, 247-253.

Cronbach, L. J. (1970). Essentials of psychological testing. New York: Harper \& Row.

Davies, J. (2012). Facework on Facebook as a new literacy practice. Computers \& Education, 59(4), 1929.

Davis, F. D. (1989). Perceived usefulness, perceived ease of use, and user acceptance of information technology. MIS Quarterly, 13(3), 319-339.

Dohn, N. (2009). Web 2.0: inherent tensions and evident challenges for education. Computer Supported Collaborative Learning, 4, 343-363.

Ellison, N.B ., Steinfield, C., \& Lampe, C. (2007). Social capital and college students' use of online social network sites.Journal of Computer-Mediated Communications, 12, 1143-1168.

Everson, M., Gundlach, E., \& Miller, J. (in press). Social media and the introductory statistics course. Computers in Human Behavior, doi: http://dx.doi.org/10.1016/j.chb.2012.12.033. 
Falk, R. F., \& Miller, N. (1992). A primer for soft modelling. Akron, Ohio: University of Akron Press.

Fornell, C., \& Larcker, D. F. (1981). Evaluating structural equation models with unobservable variables and measurement error: algebra and statistics. Journal of Marketing Research, 18(1), 39-50.

Fox, A. B., Rosen, J., \& Crawford, M. (2009). Distractions, distractions: Does instant messaging affect college students' performance on a concurrent reading comprehension task? Cyberpsychology and Behavior, 12, 51-53.

Fried, C. B. (2008). In-class laptop use and its effects on student learning. Computers and Education, 50, 906-914.

Gefen, D., Straub, D. W., \& Boudreau, M. C. (2000). Structural equation modeling and regression: guidelines for research practice. Communications of the Association for information Systems, 4(7), 170 .

Gerbing, D. W., \& Anderson, J. C. (1988). An updated paradigm for scale development incorporating unidimensionality and its assessment. Journal of Marketing Research, 25, 186-192.

Gray, K., Annabell, L., \& Kennedy, G. (2010). Medical students' use of Facebook to support learning: Insights from four case studies. Medical Teacher, 32, 971-976.

Greenhow, C., Robelia, B., \& Hughes, J.E. (2009). Learning, teaching, and scholarship in a digital age: Web 2.0 and classroom research: What path should we take now? Educational Researcher, 38, 246.

Gruzd, A., Staves, K., \& Wilk, A. (2012). Connected scholars: Examining the role of social media in research practices of faculty using the UTAUT model. Computers in Human Behavior, 28, 23402350.

Hew, K. F. (2011). Students' and teachers' use of Facebook. Computers in Human Behavior, 27, 662676.

Hsu, S. H., Chen, W. H., \& Hsieh, M. J. (2006). Robustness testing of PLS, LISREL, EQS and ANNbased SEM for measuring customer satisfaction. Total Quality Management, 17(3), 355-371.

Huang, W., Hood, D., \& Yoo, S. (2013). Gender divide and acceptance of collaborative Web 2.0 applications for learning in higher education. Internet and Higher Education, 16, 57-65.

Hulland, J. (1999). Use of partial least squares (PLS) in strategic management research: a review of four recent studies. Strategic Management Journal, 20(2), 195-204.

Jimoyiannis, A., \& Angelaina, S. (2012). Towards an analysis framework for investigating students' engagement and learning in educational blogs. Journal of Computer Assisted Learning, 28, 222-234.

Jones, N., Blackey, H., Fitzgibbon, K., \& Chew, E. (2010). Get out of MySpace! Computers \& Education, 54(3), 776-782.

Judd, T. (2014). Making sense of multitasking: The role of Facebook. Computers and Education, 70, 194202.

Junco, R. (2012). The relationship between frequency of Facebook use, participation in Facebook activities, and student engagement. Computers \& Education, 58, 162-171.

Junco, R., \& Cotton, S. R. (2011).Perceived academic effects of instant messaging use. Computers and Education, 56, 370-378.

Junco, R., \& Cotton, S. R. (2012).The relationship between multitasking and academic performance. Computers and Education, 59, 505-514. 
Karpinski, A. C., Kirschner, P. A., Ozer, I., Mellott, J. A., \& Ochwo, P. (2013). An exploration of social networking site use, multitasking, and academic performance among United States and European university students. Computers in Human Behavior, 29, 1182-1192.

Kim, S. S., \& Malhotra, N. K. (2005). A longitudinal model of continued IS use: an Integrative view of four mechanisms underlying post-adoption phenomena. Management Science, 51(5), 741-755.

Kim, S. S., Malhotra, N. K., \& Narasimhan, S. (2005). Two competing perspectives on automatic use: a theoretical and empirical comparison. Information Systems Research, 16(4), 418-432.

Kushin, M. J., \& Yamamoto, M. (2010). Did social media really matter? College students' use of online media and political decision making in the 2008 election. Mass Communication and Society, 13, 608630 .

Lévy, J. P., Valenciano, J., \& Michal, T. (2009). Modeling distribution channel dynamics of North American cars in the Spanish automovile industry. International Advances in Economic Research, 15, 186-206.

Limayem, M., Hirt, S. G., \& Cheung, C. M. K. (2007). How habit limits the predictive power of intentions: the case of IS continuance. MIS Quarterly, 31(4), 705-737.

Lopez-Nicolas, C., Molina-Castillo, F. J., \& Bouwman, H. (2008). An assessment of advanced mobile services acceptance: Contributions from TAM and diffusion theory models. Information \& Management, 45, 359-364.

Luzon, M. J. (2009). Scholarly hyperwritting: The function of links in academic weblogs. Journal of the American Society for Information Science and Technology, 60(1), 75-89.

Martin, S., Diaz, G., Sancristobal, E., Gil, R., Castro, M., \& Peire, J. (2011). New technology trends in education: Seven years of forecasts and convergence. Computers \& Education, 57, 1893-1906.

McCarthy, J. (2013). Learning in Facebook: First year tertiary student reflections from 2008 to 2011. Australasian Journal of Educational Technology, 29(3), 337-356.

Muñoz, C., \& Towner, T. (2009). Opening facebook: How to use Facebook in the college classroom. Society for information technology \& teacher education international conference, Chesapeake (USA).

Nunnally, J. C. (1978). Psychometric theory (2nd ed.). New York: McGraw-Hill.

Pashler, H. (1994). Dual-task interference in simple tasks: data and theory. Psychological Bulletin, 16, 220-244.

Rambe, P. (2012). Activity theory and technology mediated interaction: Cognitive scaffolding using question-based consultation on Facebook. Australasian Journal of Educational Technology, 28(8), $1333-1361$.

Rambe, P. (2013). Converged social media: Identity management and engagement on Facebook Mobile and blogs. Australasian Journal of Educational Technology, 29(3), 315-336.

Roblyer, M. D., McDaniel, M., Webb, M., Herman, J., \& Witty, J. V. (2010). Findings on Facebook in higher education: A comparison of college faculty and student uses and perceptions of social networking sites. Computers \& Education, 13, 134-140.

Rosen, L. D, Carrier, L. M., \& Cheever, N. A. (2013). Facebook and texting made me do it: Mediainduced task-switching while studying. Computers in Human Behavior, 29, 948-958. 
Rowlands, I., Nicholas, D., Russell, B., Canty, N., \& Watkinson, A. (2011). Social media use in the research workflow. Learned Publishing, 24(3), 183-195.

Rubinstein, J. S., Meyer, D. E., \& Evans, J. E. (2001). Executive control of cognitive processes in task switching.Journal of Experimental Psychology: Human Perception and performance, 27(4), 763-797.

Sadaf, A., Newby, T. J., \& Ertmer, P. A. (2012). Exploring pre-service teachers' beliefs about using Web 2.0 technologies in K-12 classroom. Computers \& Education, 59, 937-945.

Schifter, D. B., \& Ajzen, I. (1985). Intention, perceived control, and weight loss: an application of the theory of planned behavior. Journal of Personality and Social Psychology, 49(3), 842-851.

Smock, A. D., Ellison, N. B., Lampe, C., \& Wohn, D. Y. (2011). Facebook as a toolkit: A uses and gratification approach to unbundling feature use. Computers in Human Behavior, 27, 2322-2329.

Terzis, V., \& Economides, A. A. (2011). The acceptance and use of computer based assessment. Computers \& Education, 56, 1032-1044.

Terzis, V., Moridis, C. N., \& Economides, A. A. (2012).The effect of emotional feedback on behavioral intention to use computer based assessment. Computers \& Education, 59, 710-721.

Thong, J. Y. L., Hong, S. J., \& Tam, K. Y. (2006).The effects of post-adoption beliefs on the expectationconfirmation model for information technology continuance. International Journal of HumanComputer Studies, 64(9), 799-810.

Van der Heijden, H. (2004). User acceptance of hedonic information systems. MIS Quarterly, 28(4), 695 704.

Veletsianos, G. (2012). Higher education scholars' participation and practices on Twitter. Journal of Computer Assisted Learning, 28, 336-349.

Venkatesh, V., Morris, M. G., Davis, G. B., \& Davis, F. D. (2003). User acceptance of information technology: toward a unified view. MIS Quarterly, 27(3), 425-478.

Venkatesh, V., Thong, J. I .L., \& Xu, X. (2012). Consumer acceptance and use of information technology: extending the unified theory of acceptance and use of technology. MIS Quarterly, 36(1), 157-178.

Wang, Y., Wu, M., \& Wang, H. (2009). Investigating the determinants and age and gender differences in the acceptance of mobile learning. British Journal of Educational Technology, 40(1), 92-118.

Werts, C. E., Linn, R. L., \& Jöreskog, K. G. (1974). Intraclass reliability estimates: testing structural assumptions. Educational and Psychological Measurement, 34(1), 25-33.

Westerman, J. (2006-2007). When motivating Generation Y in the classroom. Essays on Teaching Excellence, 18(5), 1-41.

Wold, H. (1985).Partial least squares. In S. Kotz, \& N. L. Johnson (Eds.), Encyclopedia of statistical sciences (vol. 6, pp. 581-591). New York: Wiley.

Wood, E., Zivcakova, L., Gentile, P., Archer, K., De Pasquale, D., \& Nosko, A. (2012). Examining the impact of off-task multi-tasking with technology on real-time classroom learning. Computers \& Education, 58, 365-374. 
Australasian Journal of Educational Technology, 2014, 30(2).

Corresponding author: Tomás Escobar-Rodríguez, tescobar@uhu.es

Australasian Journal of Educational Technology (C) 2014.

Please cite as: Escobar-Rodriguez, T., Carvajal-Trujillo, E., \& Monge-Lozano, P. (2014). Factors that influence the perceived advantages and relevance of Facebook as a learning tool: An extension of the UTAUT. Australasian Journal of Educational Technology, 30(2), 136-151. 